\title{
Correction to: Breast cancer subtype discordance: impact on post-recurrence survival and potential treatment options
}

Peter F. McAnena ${ }^{1}$, Andrew McGuire ${ }^{1}$, A. Ramli' , C. Curran', C. Malone², R. McLaughlin², K. Barry², James A. L. Brown ${ }^{1 *}$ and M. J. Kerin ${ }^{1}$

\section{Correction to: BMC cancer (2018) 18:203}

DOI: https://doi.org/10.1186/s12885-018-4101-7

It has been highlighted that the original manuscript [1] contains a typesetting error regarding the authorship and did not mention the name of Andrew McGuire. The authorship was incorrectly captured as Peter F. McAnena ${ }^{1}$, James AL Brown ${ }^{1}$, A. $\operatorname{Ramli}^{1}$, C. Curran $^{1}$, C. Malone ${ }^{2}$, R. McLaughlin ${ }^{2}$, K. Barry ${ }^{2}$, Brown $\mathrm{JAL}^{1 *}$ and M. J. Kerin ${ }^{1}$ in the original article. The correct authorship is: Peter F. McAnena ${ }^{1}$, Andrew McGuire ${ }^{1}$, A. Ramli $^{1}$, C. Curran ${ }^{1}$, C. Malone ${ }^{2}$, R. McLaughlin ${ }^{2}$, K. Barry $^{2}$, James A.L. Brown ${ }^{1 *}$ and M. J. Kerin ${ }^{1}$. The original article has been updated.

\section{Author details}

'Discipline of Surgery, Lambe Institute for Translational Research, School of Medicine, National University of Ireland Galway, Galway, Ireland. ²Discipline of Surgery, Galway University Hospital, Galway, Ireland.

Received: 28 February 2018 Accepted: 28 February 2018

Published online: 13 March 2018

\section{Reference}

1. McAnena, et al. Breast cancer subtype discordance: impact on post-recurrence survival and potential treatment options. BMC Cancer. 2018;18:203. https://doi. org/10.1186/s12885-018-4101-7.

\footnotetext{
* Correspondence: james.brown@nuigalway.ie

'Discipline of Surgery, Lambe Institute for Translational Research, School of

Medicine, National University of Ireland Galway, Galway, Ireland
} 